\title{
Correction to: Microstructure and Thickness Effects on Impact Behavior and Separation Formation in X70 Pipeline Steel
}

\author{
EMILY B. MITCHELL (1), ${ }^{1,4}$ ENRICO LUCON ${ }^{2}$ LAURIE E. COLLINS, ${ }^{3}$ \\ AMY J. CLARKE, ${ }^{1}$ and KESTER D. CLARKE ${ }^{1}$ \\ 1.-Department of Material and Metallurgical Engineering, Colorado School of \\ Mines, Golden, CO 80401, USA. 2.-Applied Chemicals and Materials Division, National \\ Institute of Standards and Technology, Boulder, CO 80303, USA. 3.-Process and Product \\ Development, EVRAZ North America, Regina, SK S4P 3C7, Canada. 4.-e-mail: emitchel@mines.edu
}

\section{Correction to:}

\section{JOM}

https://oi.org/10.1007/s11837-021-04562-9

This article was updated to correct duplication of author names in the reference lists.
Publisher's Note Springer Nature remains neutral with regard to jurisdictional claims in published maps and institutional affiliations. 